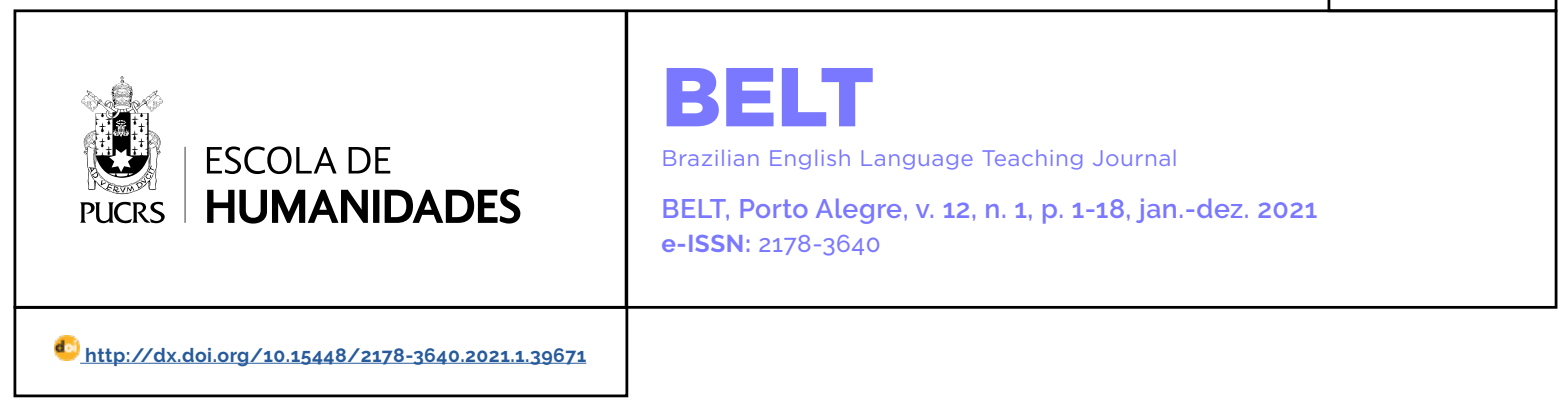

SEÇÃO ARTIGO

\title{
Social activity and learning de-encapsulation under a multimodal approach in English Language Teaching
}

\author{
Atividade Social e desencapsulação da aprendizagem sob um viés multimodal no \\ ensino de lingua inglesa \\ Actividad social y desencapsulación del aprendizaje bajo la perspectiva multimodal en \\ la enseñanza de la lengua inglesa
}

\section{Carolina Favaretto}

Santos ${ }^{1}$

orcid.org/0000-0002-5137-0066/ carolinafavaretto7@gmail.com

\section{Denise Ismenia}

Grassano Ortenzi ${ }^{1}$

orcid.org/0000-0003-2125-3130

denise@uel.br

Recebido em: 30/11/2020

Aprovado em: 17/05/2021.

Publicado em: 16/06/2021.

\section{(c) (i)}

Artigo está licenciado sob forma de uma licença Creative Commons Atribuição 4.0 Internacional.
Abstract: In order to attempt to bring language learning practices closer to students' daily lives, studies regarding Social Activity (Liberali, 2009), under the Social Historical Activity Theory (Engestrom, 1999) have been gaining space in current research (Larré, 2018; Silva, 2017; Zanella, 2017). Accordingly, as an emerging necessity from the context here described and from our society in general, environmental education became necessary, along with interdisciplinary practices, as stated in Brazil's official curriculum guidelines. In addition, in the $21^{\text {st }}$ century, with the advances of Information and Communication Technologies (ICT), the Pedagogy of Multiliteracies (Cope \& Kalantzis, 2001) has become even more relevant in education, being it due to communication, social media, video, and images, for example. In light of this, the objective of this research paper is to analyze the outcome of an environmentally focused pedagogical intervention under a multimodal approach, developed during an internship program in a state school. After being in contact with planetary awareness in English language lessons, students customized ecobags alongside the Arts teacher, in an interdisciplinary way. Students' productions were analyzed taking into account their multimodal choices when making meaning out of different semiotic modes, and to what extent learning de-encapsulation happened in this process. Results indicate that students were able to achieve synesthesia in their multimodal productions, combining linguistic, visual, spatial and gestural modes. Furthermore, learning de-encapsulation occurred as students made use of the environmental knowledge they acquired in English classes, not only by crossing boundaries inside the school, but also outside its walls.

Keywords: social activity, multimodality, learning de-encapsulation, interdisciplinary practice

Resumo: Buscando tornar práticas de aprendizagem de línguas mais próximas da vida dos estudantes, estudos relacionados à Atividade Social (Liverali, 2009), sob a perspectiva da Teoria da Atividade (Engestrom, 1999), vem ocupando espaço atualmente (Larré, 2018; Silva, 2017; Zanella, 2017). Do mesmo modo, como uma necessidade emergente do contexto neste artigo descrito, e também de nossa sociedade como um todo, a educação ambiental tornou-se necessária, juntamente com práticas interdisciplinares, presentes em documentos oficiais do governo brasileiro. Além disso, no século XXI, com os avanços das Tecnologias de Informação e Comunicação (TICs), a Pedagogia dos Multiletramentos (Cope \& Kalantzis, 2001) se tornou cada vez mais presente dentro de sala de aula, por meio da comunicação, redes sociais, vídeos e imagens, por exemplo. Por esse viés, o objetivo deste artigo é analisar os resultados de uma intervenção pedagógica, com foco em educação ambiental, sob uma perspectiva multimodal, desenvolvida em uma escola estadual. Após terem contato com aulas sobre conscientização planetária nas aulas de lingua inglesa, os alunos customizaram sacolas ecológicas interdisciplinarmente com a professora de Artes. As produções foram analisadas levando em consideração escolhas multimodais feitas ao construirem 
sentido a partir de diferentes meios multisemióticos e, também, como a desencapsulação da aprendizagem ocorreu durante esse processo. Os resultados indicam que os alunos foram capazes de atingir sinestesia em suas produções multimodais, combinando meios linguísticos, visuais, gestuais e espaciais. Ademais, a desencapsulação da aprendizagem ocorreu quando os estudantes utilizaram o conhecimento ambiental adquirido não somente cruzando barreiras dentro da escola, mas também ultrapassando seus muros.

Palavras-chave: atividade social, multimodalidade, desencapsulação da aprendizagem, prática interdisciplinar

Resumen: Buscando acercar las prácticas de aprendizaje de idiomas a la vida de los estudiantes, los estudios relacionados con la Actividad Social (Liberali, 2009), bajo la perspectiva de la Teoría de la Actividad (Engestrom, 1999) ha venido ocupando espacio hoy (Larré, 2018; Silva, 2017; Zanella, 2017). Asimismo, como una necesidad emergente del contexto en este artículo descrito, y también de nuestra sociedad en su conjunto, la educación ambiental se ha vuelto necesaria, junto con prácticas interdisciplinarias, presentes en documentos oficiales del gobierno brasileño. Además, en el siglo XXI, con los avances de las Tecnologias de la Información y la Comunicación (TIC), la Pedagogía de la Multialfabetización (Cope \& Kalantzis, 2001) se ha vuelto cada vez más presente dentro del aula, a través de la comunicación, las redes sociales, videos e imágenes, por ejemplo. En consecuencia, el objetivo de este artículo es analizar los resultados de una intervención pedagógica, con foco en la educación ambiental, desde una perspectiva multimodal, desarrollada en una escuela pública. Después de tener contacto con las clases de conciencia planetaria en las clases de idioma inglés, los estudiantes personalizaron bolsas ecológicas de manera interdisciplinaria con el profesor de Artes. Las producciones se analizaron teniendo en cuenta las elecciones multimodales realizadas al construir el significado a partir de diferentes medios multisemióticos, y también cómo se produjo la desencapsulación del aprendizaje durante este proceso. Los resultados indican que los estudiantes lograron sinestesia en sus producciones multimodales, combinando medios lingüisticos, visuales, gestuales y espaciales. Además, la desconexión del aprendizaje se produjo cuando los estudiantes utilizaron los conocimientos ambientales adquiridos no solo cruzando barreras dentro de la escuela, sino también cruzando sus muros.

Palabras clave: actividad social, multimodalidad, desencapsulación del aprendizaje, práctica interdisciplinar

Nowadays, especially with the influence of modernity, globalization and advances of information and communication technology (ICT), the English language has made itself more and more present in an individual's routine. When inserted in an educational setting, one should learn how to use a language in order to constitute themselves as subjects (Leffa \& Irala, 2014). Hence, as an active subject, one shall get prepared for being a citizen with independence and autonomy in order to act in the world with the help of a language. However, when it comes to foreign language teaching in Brazilian primary and secondary education, the lessons taught tend to be far from the reality of every day conversation (Rezende, 2011). In the process of English language teaching and learning in state schools, this aspect has been debated regarding the possibilities for students to use language in their daily lives in a way that is meaningful for them (Liberali, 2009).

Studying the English language can contribute to the exercise of active citizenship, besides enhancing the possibilities of interaction. According to the curricular guidelines issued by the Brazilian Ministry of Education, Base Nacional Comum Curricular (BNCC) (Brasil, 2017), learning the English language provides the creation of new ways of engagement and participation of students in a globalized world. The document also proposes the discussion of topics considered important and relevant to students, being one of these topics environmental education.

Environmental education became mandatory with the publishing of the Brazilian's 1988 Constitution and was incorporated to national public policies with the approval of The National Environmental Education Policy. This document asserts that such public sphere must promote environmental and conservation awareness and praxis in every level of education (BRASIL, 1988). The National Program of Environmental Education (ProNEA) based on the law nº 9.795 (Brazil, 1999) states that environmental education is the action of building social values, knowledge, abilities, attitudes and competences for the environmental conservation (Chapter 1, Article ${ }^{\text {st) }}$. It also affirms that such action should be developed through the production and distribution of educational material (Chapter 2, Article $8^{\text {th }}$ ).

This theme has already been researched (Cristovão et al., 2016; Rezende, 2014; Fracalanza, 2004; Sousa et al., 2001; UNESCO, 1976), approaching environmental education, focusing on its importance in the classroom and the concern about students' and teachers' awareness on the topic. Nevertheless, Brazilian public schools still lack the application of concrete environmental education proposals in basic levels by using English 
language as an instrument of learning. In light of this, I have decided to develop and apply a pedagogical intervention based on the principle of Social Activity, as discussed by Liberali (2009), aiming at individual and collective participation in English classes with a practical result and action that surpasses classroom boundaries involving environmental education.

The process of teaching through Social Activity (Liberali, 2009) emphasizes performing a group of actions to achieve a specific motive/ object, meeting people's daily life necessities. In these terms, its organization is in line with elements from the Social Historical Activity Theory (Engestrom, 2002): subject, mediating artifacts, object, community, rules, and division of labor. The outcome consists of an action in the world. This paper aims to analyze the affordances of learning de-encapsulation through multiliteracies (Cope \& Kalantziz, 2000) in the social activity of the customization and distribution of ecobags by students of the $9^{\text {th }}$ year of a Brazilian state school. In agreement with this, this study intends to answer the following research questions: (a) How do students make meaning out of the organization of multimodal choices in the customization of the ecobags? (b) Is there any evidence of learning deencapsulation in the social activity here proposed?

This action derives from the multiliteracies proposal based on discussions from The New London Group (1996/2000). These discussions suggest the development of resources to deal with social-historical differences. For that, multiple ways of reality comprehension, that exist in various ways and media, start being a part of the discussion, elaboration, construction, and implementation of pedagogical proposals of curricular transformation (Liberali et al., 2015).

This article starts with a section of literature review, with theoretical foundation needed for further analysis: Social Activity (Liberali, 2009); Social Historical Activity Theory and Learning De-encapsulation (Engestrom, 2002); Multiliteracies (Cope \& Kalantziz, 2000) and Environmental Education (UNESCO, 1976). Then, in the methodology section, data collection and data analysis procedures are explained, along with details and ethical concerns from pedagogical activities within the intervention. Subsequently, results are presented by analyzing the outcomes of the social activity, focusing on learning de-encapsulation and multimodal choices. To conclude this last segment, discussions on practical didactic activeness towards environmental literacy will be shared for upcoming considerations in basic education.

\section{Literature review}

The current society has been facing some considerable changes regarding the influence of technology in the means of communication, in social interactions and in social practices. Along with that, the environment has been responding to human actions and advances. Because of these developments, planetary awareness became necessary in education. Due to all these changes above mentioned, measures were to be taken regarding classroom practices and methodologies. In this section, the theoretical framework will be presented to illustrate and support pedagogical practices that were performed in the intervention described in this paper.

\section{Social Activity}

After many years of contributions from several learning theories, teaching practices, methodologies, and approaches, such as Behaviorism (Skinner, 1978), Constructivism (PIAGET, 1980), Social-historical-cultural Perspective (Vygotsky, 2001), a common ground was found in order to fulfill contemporary demands from learners. Kumaravadivelu (2005), for instance, proposes the term Post-method to deal with the advantages and, at the same time, limitations of different methods, proposing the construction of new theories of practice considering the needs to connect theory and practice.

Applying to that, a post-method (Kumaravadivelu, 2005) emerged, which was called Social Activity (Liberali, 2009). In the present social context, language should meet daily-basis needs so one may transform society through a better participation and coexistence. Therefore, the learning process should be meaningful for students, working as a 
bridge for them to act as active citizens in the world. In this sense, teaching practices should aim at working with reflections about real life experiences, interacting with social and historical contexts, based on a real necessity (Liberali, 2009).

In the book "Social Activity in Foreign Language Classes", Liberali (2009) explains that a Social Activity allows the creation of Zones of Proximal Development (ZPDs). That is "the distance between the actual developmental level as determined by independent problem solving and the level of potential development as determined through problem-solving under adult guidance, or in collaboration with more capable peers" (Vygotsky, 1978, p. 86). Moreover, as Holzman (2010) highlights, the ZPD can be seen in a collective way, "at other times Vygotsky emphasized more clearly that the socialness of learning-leading-development is collective, that the ZPD is not exclusively or even primarily a dyadic relationship, and that what is key to the ZPD is that people are doing something together." (p. 5). According to Holzman's analysis of Vygostky's work, "a qualitative transformation is a collective accomplishment." (p. 5). In this perspective, language involves teachers and students in meaningful collaboration according to a real necessity expressed by the community. In this regard, Social Activity acknowledges innovative social and cultural practices, sometimes atypical for students, by implementing different instruments, conceptions, and cognitive processes. All of this allows students to have a new and different perspective of the world.

Liberali (2009) demonstrates that in order to organize a didactic project as a social activity, educators should take into consideration several steps, such as: a) Find a relevant topic for the students and for the institution; b) Establish partnerships with teachers from other areas, working with the topic in an integrated way; c) Identify learning expectations and developments through the activity; d) Overcome the separation between life in school and real life; think of ways to approximate them; e) Plan and organize procedures, taking into account social-historical elements and previous knowledge of the students; f) Assess and evaluate this process, allowing students to notice their development.

In agreement with Liberali (2009), the Brazilian Annual Document of Basic Education (Anuário Brasileiro da Educação Básica, 2013), suggests a renewing national program with the objective of promoting pedagogical practices with interdisciplinary approaches, focused on theory and practice. These approaches focus on the study of activities in which subjects interact with one another in specific cultural and historically dependent contexts. This means that a student, for example, is filled with necessities and interests that can be enhanced by the learning process, based on social-historical characteristics of the moment they have been living in.

Richter (2015) meets this concept by adding that it is through a Social Activity that students (re)build their identity and think of new ways of acting in society. This can happen through actual living situations that enable the development of autonomy, responsibility, and responsiveness to possible life events. Therefore, learners can notice the relevance in the proposed activities and consider him/herself a citizen of the world. Larré (2018) emphasizes it by saying that Social Activities facilitate the participation in social contexts that intertwine with real life.

Overall, when one thinks of teaching through Social Activities, it is essential that students have access to real life situations. This can be done by experimenting, roleplaying, questioning, and reflecting ways of dealing with circumstances in life. Such actions may give students the opportunity to understand and transform the world (Richter, 2015). The pedagogical intervention explained and presented in this article was shaped according to this concept, since it emerged from a concrete necessity. Such necessity derived from both social customs (taking care of the environment) and political issues (official documents from the Brazilian Ministry of Education).

Didactic activities found in the lesson plans for the intervention, mentioned in the methods section of this paper, looked for targeting second language acquisition through social activities, involving not only learning the language itself, but also building 
planetary awareness and instigating positive action towards the "life that is lived" (Marx \& Engels, 2006) through the English language. Having the purpose of deepening the discussion about teaching and learning processes based on Social Activities, the following section discusses the fundamentals of the Social-Historical Activity Theory.

\section{Social-Historical Activity Theory and Learning de-encapsulation}

Social-historical events and changes have been a topic of study for a long time. Marx (1989) for instance, mentioned the historical and social development of men in his early philosophical studies, having labor as a main bond that connected humans to the world. Vygotsky (1984) follows this line of thought by stating that the human being is dependent on social-historical activities in order to develop his/ her psyche. According to him, the emergence of consciousness is related to human activity through social interactions.

Embedded on Marx and Vygotsky's studies, Leontiev (1992) first used the Social-Historical Activity Theory term by gathering influences from several currents on social and historical modifications. Leontiev believes that a human activity comes from necessities that guide motives oriented by an object (Libâneo, 2004). In other words, real necessities create a motive for achieving something. This motive requires an object that is present in numerous actions to reach that specific goal. Recent studies regarding this theory enhance social topics such as contextualized activities, social activeness as a means of learning, identity, institutional practices, and social diversity (Libâneo, 2004). Such processes happen because social and historical factors work as mediators for activities.

In the book Learning and Expanding with Activity Theory, Sannino (2009) expresses that the Activity Theory "seeks to analyze development within practical social activities; in activities, humans develop their skills, personalities, and consciousness" (p. 1). Likewise, through activities, subjects can transform their social conditions, resolve contradictions, generate new cultural artifacts, and create new forms of existing. According to Engestrom (1999), the SocialHistorical Activity Theory focuses on the studies of activities in which subjects interact with one another in cultural contexts that are historically dependent and coexistent. He also affirms that behind every human action, there is the desire of reaching ways of satisfying their necessities.

According to this theory, subjects wish for an object, therefore they act inside a specific community, with established rules and division of labor. This process does not happen in an isolated way since all the activities are connected among themselves. As Liberali (2009) explains, an activity, sustained by rules, division of labor and community, happens among three basic items: the subjects, the object, and the instruments. Such instruments are found between the subjects that act and the objects or situations in which they act on.

Research has been carried out about the problematic of the distance between schoollife and real-life (Resnick, 1987; Torres Santomé, 1998; Engestrom, 2002); therefore, the need of a curriculum and learning de-encapsulation appeared. According to Liberali and Magalhães et al. (2015), usually, contents in the classroom are usually approached in a decontextualized way, far from the sensible world and isolated; this gap avoids connections and constructions of meanings by the students. Moreover, students end up not acting as operating citizens, being alienated from their own community's concreteness.

Social-Historical Activity Theory emerges from the principle of bringing together the relationship between the school knowledge offered by textbooks and a particular interest/necessity nurtured by the school community (Engëstrom, 2002). Accordingly, learners must have the opportunity to deal with meaningful knowledge that will be useful for them outside classroom walls. By dealing with an instrument and object that is desirable, yet not completely present in the textbook, but adapted to real-life situations, students have the chance to "acquire a further activity while creating it" (Engestrom, 2002, p. 3).

The relationship between traditional learning and a real necessity changes once students and teachers 
expand the object of learning by trespassing classroom boundaries. It gives space to a context discovery and a practical application of learning because students would be "transforming the activity of school learning itself from within" (Engestrom, 2002, p. 3). This so-called de-encapsulation of learning exploits the existing conflicts and needs among teachers, students, parents, and others involved in the school community.

Lave and Wenger (1991) support this theory based on the notion of learning as a gradually increasing participation in a "community of practice". The authors claim that "social practice is the primary, generative phenomenon, and learning is one of its characteristics" (p. 6g). Therefore, learning should be seen as an integral part of a social system, working actively in the community in which it is occurring. To this extent, learning de-encapsulation should originate from a situated issue in need for attention present in a community, resulting in a Social Activity in a coexistent social and historical period.

The intervention in this study focuses on an activity derived from the necessity to work with practical and meaningful environmental education issues in the classroom. The expected result is not only to raise planetary awareness, but also to surpass classroom/school boundaries through learning de-encapsulation in the English language, involving activities in a multimodal approach.

\section{Multiliteracies}

As discussed in the previous section, a Social Activity emerges from a real necessity found in a social-historical moment one has been living in. When it comes to our current scenario, it is indispensable to notice that the advances of Information and Communication Technology (ICT) are present and influence our daily basis more and more each day. Customs have been changing along with technological advances; interaction nowadays is mediated by social media and communication apps, for example. Besides, "modes of meaning, that were relatively separated, become ever-more closely intertwined" (Cope \& Kalantzis, 2009, p. 3). Based on these facts, classroom activities are also affected, bringing the need of a new way of thinking and dealing with pedagogical practices.

Cope and Kalantzis (2008) clarify that the term "Multiliteracies" appeared essentially due to some of the changes in our contemporary communications environment. In the past, the term "literacy" could be simply understood as the ability of putting words together in sentences correctly according to standard rules. Now, the term "literacies" (in the plural) is inevitably necessary. Firstly, because English is becoming a global language (CRYSTAL, 1997), so the many kinds of English literacies work in many different cultural, social, or professional contexts. Thus, these differences have reached high importance in communication (Cope \& Kalantzis, 2008). Secondly, there is the nature of new communication technologies, where meaning is built in increasingly multimodal ways; For instance, "written-linguistic modes of meaning attach to visual, audio, gestural and spatial patterns of meaning" (Cope \& Kalantzis, 2008, p. 198).

In consonance with this, in 1996, The New London Group presented the Pedagogy of Multiliteracies. It was a proposal of a new educational practice that embraces modern changes regarding habits and ways of communicating. This group adverts traditional methods of teaching which use the written language as the only instrument of learning since it is almost impossible to find such a monomodal style of communication in current society. Instead, they favor the embrace of multimodal texts, exploring human capability of expressing itself fully through language. According to the Group, the term multiliteracies was chosen "to describe two important arguments we might have with emerging cultural, institutional, and global order: the multiplicity of communication channels and media, and the increasing saliency of cultural and linguistic diversity" (Cazden; Cope et al, 1996, p. 63).

Summarizing the ideas of The New London Group, Brener (2018) reports that the term Multiliteracies refers to two dimensions: multilingual and multimodal. The first one addresses social diversities, such as, language use among minorities, discursive differences, different identities, and different literacies 
regarding cultural diversification. The second one, called Multimodality, claims that the construction of meaning is active and dynamic, through several ways of communication and interaction with the world and with other people.

Kress (2000) defines multimodality as an interaction among speaking, writing, reading images and others in order to create meaning. This cooperation involving multisemiotic ways is present nowadays, especially with the development of the ICTs. Students, as the ones who joined this research, enjoy these new technologies in a daily basis. Social media such as Facebook, WhatsApp, Instagram and Twitter take an important part in the communication process; texts, sounds, videos, images, emojis are part of these teenagers' reality. Consequently, it influences directly on their performance and behavior inside the classroom and in the social community. As proposed by The New London Group (2000), a multimodal pedagogy makes itself necessary inside teaching practices.

With the "orchestration" of modes (Kress, 2014, p. 14), that is, by integrating different modes together, a new perspective/construction of meaning becomes possible, since they are connected to the "inherent 'multiness' of human expression and perception" (Cope \& Kalantzis, 2009, p. 423), bringing to surface the concept of synesthesia. In the Multiliteracies Theory, researchers refer to synesthesia as a way of switching representational modes (parallels) to convey the same or a similar meaning. As Cope and Kalantzis describe, "We can describe in words scenes that might otherwise be represented with pictures, or represent three dimensional spaces visually in two dimensions, or represent through the gesture language of signing what might otherwise have been said in spoken words" (2009, p. 423).

Kress (2010) emphasizes that literacy cannot be separated from social, technological, and economic factors. All these factors contribute to a new understanding of communication representations. Multiliteracies, Social Activities and The SocialHistorical-Activity Theory dialogue in the sense that the ongoing society has been facing social and cultural changes, bringing the urgency of changes in teaching practices. Therefore, the classroom should be considered a place where multimodal activities can be found. Teachers may benefit from enriching pedagogical procedures that innovate the way of teaching and learning (Heberle, 2012).

In this context, more actions should be taken to foster students' "multimodal communicative competence" (Royce, 2007), which involves "the knowledge and use of language concerning the visual, gestural, audio and spatial dimensions of communication (Heberle, 2010, p. 102). A new multimodal literacy is crucial to our insertion in a world where meanings increasingly emerge in many different forms (Cope \& Kalantzis, 2000). Accordingly, teachers should follow the evolution of modernity and engage on pedagogical activities that favor students, meeting their needs in a meaningful way and engaging them to participate actively as agents in the world.

As stated by Cope and Kalantzis (2008), learners should learn how to use language to create meaningful and critical connections through it in order to act in the real world. Once a learning process is taken out of students' context, it loses its meaning, therefore, its relevance. This indicates that the teacher should also present a "multiple, inter/ transdisciplinary" (Oliveira \& Szundy, 2014, p. 192) methodology, bringing classroom practices closer to the realness of learner's everyday life. Bezerra (2011) talks about "situated practice", which refers to "the need to approach whatever meaning-making resource from the starting point of the personal experiences of students so that they can locate themselves in relation to the study to be done" (Bezerra, 2011, p. 168). It meets with the fact that "meanings belong to culture, rather than to specific semiotic modes" (Kress \& Van Leeuwen, 2010, p. 102).

Such multiple modes of comprehension and communication are intertwined and connected to a bigger meaning, related to cultural, social, and historical factors. Bill Cope and Mary Kalantzis (2009) illustrate this parallelism between modes with the Grammar of Multimodality in response to five questions: "1. Representational: What do the meanings refer to?; 2. Social: How do the meanings connect the persons they involve?; 3. Organizational: How do the meanings hang 
together?; 4. Contextual: How do the meanings fit into the larger world of meaning?"; 5. Ideological: Whose interests are the meanings skewed to serve?" (p. 365). Based on these questions, the authors evidenced that modes of meaning work together in different modes of representation. In other words, meanings are built through many other multiple modes of meaning found in multimodal means of representation. In order to incorporate meaning in a society full of changes and that is continuously evolving, multimodal materials should be taken into consideration when incorporated inside a classroom, for example.

The process of integration among different modes is inherent to the human being. It occurs through human interaction, perception, and expression through language. As there is no such thing as monomodal text in the present society, the Pedagogy of Multiliteracies enforces the importance of understanding how multiple texts work in order to participate in its meanings (Cope \& Kalantzis, 2008, p. 203). In this view, students in the current educational system should be molded to better adapt to the kind of the world they live now and of the near future. In conclusion, students should be able to understand how these multimodal texts work in order to reach a further meaning.

\section{Environmental Education and Interdisciplinary Practice}

\begin{abstract}
Modern generations have witnessed unprecedented economic growth and technological progress, which while bringing benefits to many people, have also caused severe social and environmental consequences. [...] Recommendation 96 of the Stockholm Conference on the Human Environment called for the development of environmental education as one of the most critical elements of an all-attack on the world's environmental crisis. (A Framework for Environmental Education, UNESCO, 1976, p. 2-3)
\end{abstract}

In 1976, The United Nations Educational Scientific and Cultural Organization (UNESCO) proposed that environmental education (EE hereafter), along with the integration between the English language and environmental issues might contribute to environmental awareness and contributions, as well as promote attitudes toward habits' changes in favor of environmental education. In Brazil, EE became mandatory with the promulgation of 1988's Constitution, and it was incorporated in national policies with the approval of The National Policy of Environmental Education (PNEA), also in 1988. According to PNEA, EE must be present in every basic level education curriculum.

Congruently, The Brazilian's National Curricular Framework (BNCC, 2017) introduces the English Language Learning section of the document by saying that learning this foreign language enables students to create new forms of practical engagement in a social, plural and globalized world (p. 239). It also implies that students should use the English Language as an instrument to exercise active citizenship, connecting political and pedagogical practices. The official document addresses its policies not only to teachers, but also to schools by saying that these institutions should incorporate contemporary topics that affect human life in local, national and global scales, taking into account an integral and interdisciplinary method. One of these topics, provided by law, is environmental education (Law n 9.795/1999) (Brazil, 2017, p. 21).

Dias (2003) affirms that practices regarding environmental issues solutions contribute greatly to the execution of EE in schools. Luck (2003) views EE as a dynamic and dialectic action that aims at raising awareness among humans' biological and social reality, in which the school works as a mediator under a global perspective. Therefore, since environmental problems involve not only one, but many factors, an interdisciplinary approach is necessary to combine theory and practice inside the classroom. Luck (2003) defines interdisciplinarity as a

process that concerns educators' integration
and engagement in a collective work, bringing
school subjects together in order to overcome a
fragmented educational system, aiming at hel-
ping students become active and critical citizens
towards current complex global problems. (p. 64)

Equally, Miranda et al. (2010) declares that teachers' engagement in a collaborative work, integrating different subjects, ends up connecting numerous types of knowledge, and this brings a bigger meaning to the learning process. On this 
behalf, the pedagogical intervention developed in this project follows an interdisciplinary approach. English language classes were cooperatively conducted with the discipline of Arts, in accordance with the principles of the Social Historical Activity Theory, aiming at the production and distributions of an ecologically friendly material: ecobags.

\section{Methodology \\ Nature of the research}

The nature of this study is labeled as a qualitative Action Research (Lewin, 1946; Karr \& Kemmis, 1986; Tripp, 2005). According to Tripp (2005), an Action Research is "mainly a strategy for the development of teachers as researchers, so they can improve their teaching and thus their students' learning" (p. 2). In other words, an Action research bridges the division between research and practice. The main difference between Action Research and other types of research is that it is carried by people who are concerned with the social situation that is being studied. Elliot affirms that it is a precondition of this research that the "practitioner researcher has felt the need to initiate change" (Elliott, 1991, p. 53).

\section{Context, Setting and Participants}

This research project was part of a governmental program called Pedagogical Internship Program². This program integrates The National Policy of Teachers' Formation and has the objective of promoting the improvement of the practicum in teacher education courses. This happens by providing the immersion of the pre-service teacher in the basic educational system. Such immersion must include classroom practices within a pedagogical intervention, guided by an in-service teacher from the school (cooperating teacher, CT hereafter) and advised by a professor from the university. Pre-service teachers, as myself, were funded with a scholarship in the value of $\mathrm{R} \$ 400$ by CAPES Foundation ${ }^{3}$. Due to this matter, interns must have fulfilled a workload of 440 hours within 18 months. These hours were divided among different tasks, such as, weekly meetings with the advisor, weekly meetings with the research group (including 8 other pre-service teachers), teaching practices, tests elaboration, class preparation, and academic research. State schools that were in the program were preselected by the State Department of Education, along with the groups who would join the project.

This study was held with students from the $9^{\text {th }}$ grade of a public school. It was implemented in the subject of English as a foreign language, which offered two weekly meetings of fifty minutes each. The intervention was carried out in a group of 33 students who were between 13 and 16 years old. Although students had access to a textbook, the CT chose not to use it in class; therefore, all the activities present in the intervention were elaborated by me. Nevertheless, all of them were in accordance with the school's syllabus and topics mentioned in BNCC.

This pedagogical intervention was an interdisciplinary practice, forasmuch as I attended not only English Language classes, but also Arts classes. As the customization of the bags involved artistic abilities, as well as linguistic abilities, I invited the Arts teacher to join the project. The project then was considered part of the final evaluation of the Arts subject. In total, such interdisciplinary practice (IP) took place in 6 Arts classes. This procedure meets the demands of the Pedagogical Political Plan (PPP) of the school. The latest version of the document was in 2010, and it states that IP must be present in a contextualized way in the school's disciplines, obeying the law $n^{\circ}$ 9.394/96, from the Law of Directives and Bases of National Education (LDB). However, based on observations and discussions in the school, IP almost never involves English classes.

\section{Pedagogical Intervention}

The objective of the pedagogical intervention was to raise awareness about actions and 
attitudes towards the conservation of the environment, besides working with language related to environmental awareness. During the classes, students showed signs of concern with the environment, for this matter, we aimed at addressing the subject in a critical way during classes. In the final stage, the outcome of the intervention consisted of performing the Social
Activity: customization and distribution of ecobags (ecologically friendly bags, made of cotton fabric). In order to achieve the expected result, 10 classes were developed and applied. They aimed at working with specific objectives, as well as specific themes and linguistic practices and competences, as stated in the table below.

TABLE 1 - Pedagogical intervention

\begin{tabular}{|c|c|c|c|}
\hline CLASS & THEME & OBJECTIVE(s) & TASK(s) \\
\hline 001 & $\begin{array}{l}\text { Environmental } \\
\text { problems }\end{array}$ & $\begin{array}{l}\text { To work with multimodal competences } \\
\text { and focus on their visual literacy }\end{array}$ & $\begin{array}{l}\text { Analyze illustrations from a visual narrative: } \\
\text { Omar e o Mar by Claudio Martins }\end{array}$ \\
\hline 002 & $\begin{array}{l}\text { Environmental } \\
\text { problems }\end{array}$ & $\begin{array}{l}\text { To work with image analysis and } \\
\text { vocabulary related to environmental } \\
\text { problems }\end{array}$ & $\begin{array}{l}\text { a) Analyze a picture from São Paulo } \\
\text { b) Analyze the picture they brought (homework) } \\
\text { c) Handout with environmental problems }\end{array}$ \\
\hline 003 & The 3 R's & $\begin{array}{l}\text { a) Introduce the words Reduce, Reuse, } \\
\text { Recycle. } \\
\text { b) Identify their meanings. } \\
\text { c) Listening comprehension }\end{array}$ & Song Activity: The Three R's - Jack Johnson \\
\hline 004 & $\begin{array}{l}\text { Reduce, Reuse, } \\
\text { Recycle }\end{array}$ & $\begin{array}{l}\text { Work with vocabulary and examples of } \\
\text { reduce, reuse, recycle. }\end{array}$ & $\begin{array}{l}\text { Handout activity: Put the situations under the } \\
\text { right category. }\end{array}$ \\
\hline 005 & $\begin{array}{l}\text { Reduce, Reuse, } \\
\text { Recycle }\end{array}$ & $\begin{array}{l}\text { a) Frequency Adverbs } \\
\text { b) Oral production and oral } \\
\text { comprehension }\end{array}$ & $\begin{array}{l}\text { Relate actions and situations connected to } \\
\text { the } 3 \text { R's and the frequency adverbs, }\end{array}$ \\
\hline 006 & $\begin{array}{l}\text { The use of } \\
\text { plastic (Focus } \\
\text { on plastic bags) }\end{array}$ & $\begin{array}{l}\text { a) Environmental awareness } \\
\text { b) Listening comprehension } \\
\text { c) Reading comprehension }\end{array}$ & PSA about plastic bags. \\
\hline 007 & $\begin{array}{l}\text { Environmental } \\
\text { awareness }\end{array}$ & $\begin{array}{l}\text { a) Work with slogans and imperative } \\
\text { b) Collocations }\end{array}$ & $\begin{array}{l}\text { a) Analyze ads and environmental campaigns. } \\
\text { b) Form sentences }\end{array}$ \\
\hline 008 & Ecobags & Explain the project & Review of content \\
\hline 009 & Ecobags & Brainstorm about their production & Work in groups \\
\hline 010 & Ecobags & $\begin{array}{l}\text { Show their ideas to the class and work } \\
\text { on their illustrations }\end{array}$ & Work in pairs \\
\hline
\end{tabular}

Source: the authors.

In the pedagogical intervention demonstrated above, it can be seen that environmental education was present in every class, involving multiple activities under the perspective of the multiliteracies. For instance, video activities involving the genre PSA (Public Service Announcement), environmental campaigns slogans' analysis, song about the environment, and elaboration of scaffoldings for the ecobags.

For the customization of the ecobags, I wrote a letter to a philanthropical institution of the Freemasons called Renovação Londrinense, asking for financial support and explaining the objectives and justifications of the research. The institution donated $\mathrm{R} \$ 300$ for this project, in order to buy the bags, paints and brushes for the development of the Social Activity.

The procedures for the activity consisted of three domains: linguistic, artistic and interdisciplinary. The first one involved the linguistic process 
developed in the English Classes throughout the pedagogical intervention, the second one involved artistic competence in Arts class, and the third involved the crossing of classroom's boundaries by donating the ecobag to someone outside their class. My purpose was to evidence my intentions on improving my pedagogical practices by working collaboratively in an interdisciplinary way, with an activity that would be meaningful for students, in order for them to be agents through language and trespass classroom's limitations.

\section{Data Collection Procedures}

Data for this research consist of an Intention File, which is a questionnaire regarding students' intentions behind the customization of the ecobags, their multimodal choices and de-encapsulation purposes. The Intention File contained seven questions regarding the process of the development of the social activity. The questions were: 1) What did you draw in your ecobag? Write details; 2) What colors did you use to express that? Why? What do they represent?; 3) What did you write in your ecobag?; 4) What message do you want to send with your ecobag?; 5) Who do you want to give your ecobag to? Why?; 6) What do you think about environmental awareness? Do you think it is important? Why?; 7) Did you like the classes about environmental education? Why? Students answered the questions in Portuguese, since the purpose of the intention file was to analyze their multimodal choices, not linguistic aspects related to the English Language. Pictures of the process were taken during the customization in the Arts class, and during the distribution of the bags, during English classes.

Students' parents or legal guardians received and signed an Informed Consent Form, created in agreement with the Research Ethical Committee of the State University of Londrina (Resolution $\left.n^{\circ} 63 / 2003\right)$, containing all the necessary information and clarifications for the data used in this study.

\section{Procedures for data analysis}

Data were organized according to the categorization of answers from the Intention
File filled by the students, and according to the goals of the research questions: a) How do students make meaning out of the organization of multimodal choices in the customization of the ecobags? b) Is there any evidence of learning de-encapsulation in the social activity here proposed?. The categorization happened when similar answers were gathered in groups of correspondents in relation to a given issue (Manion \& Morrison, 2007). The presentation of the findings based on the research questions was chosen in order to draw together all the relevant data for the exact issue of concern to this research. It also preserved the coherence of this material, reviewing its main objectives and possible accomplishments and achievements.

"The increasing multimodality of our representational means is the consequence in part of a series of transformations over the course of the twentieth century in the means of production and reproduction of meaning" (Cope \& Kalantzis, 2004, p. 3). Such transformations influence students' everyday activities, also in the $21^{\text {st }}$ century. For this reason, a view towards students' assignments including multimodal perspectives became necessary.

Correspondingly, data collected from the Intention File targeted studying the process of learning de-encapsulation based on two questions from A Grammar of Multimodality (Cope \& Kalantzis, 2009), under a social and ideological perspective: a) Social: How do the meanings connect the persons they involve?; b) Ideological: Whose interests are the meanings skewed to serve? This pattern also holds the division of labor for the customization, shared with the Arts teacher and the distribution of the ecobags, since they involve crossing the boundaries of the classroom.

Moreover, the final production of the ecobags aspired inquiring about the multimodal choices of the students. The materials were separated according to three questions, also based on A Grammar of Multimodality (2009): a) Representational: What do the meanings refer to? (There were separate categories according to themes, such as animals, planet Earth, pollution, 
etc.); b) Organizational: How do the meanings hang together?; c) Contextual: How do the meanings fit into the larger world of meaning? (This category regards environmental education, and the social action, for instance). Answers from every student were taken into consideration while being distributed in the categories.

\section{Analysis}

\section{Analysis of multimodal choices}

In regards to the first research question here proposed: a) How do students make meaning out of the organization of multimodal choices in the customization of the ecobags?, the outcome of the social activity performed, the ecobags, was separated in four categories to be subsequently analyzed.

The first category is Visual Representation. This category shows the representation students used in the form of illustrations to express meaning connected (or not) to the environment. This category was divided according to common themes, such as planet Earth, plants and trees, pollution, etc. The elements of this category connect to the representational and ideological questions in A Grammar of Multimodality (Cope \& Kalantzis, 2009): "What do the meanings refer to?; Whose interests are the meanings skewed to serve?" (p. 365). This happens because referring to a particular topic was a way students found to express and deliver their message.

The second item in the first category complements the first one for it exhibits the range of colors students used to depict the message they wanted to send through their production. There was a pattern found in the choice of colors to represent the natural environment, for instance, green was correspondent to trees, plants, and vegetation; blue was used for water, sky and air; brown and black were often chosen to picture a polluted and dirty impression. That might have happened because students wanted to portray a tough/realistic version of the environment, as criticism to current habits.

The following category consists of the verbal text presented in the ecobags, emphasizing the previous categories' selections for a final meaning.
This linguistic representation was achieved in the form of slogans, which were previously studied and analyzed by students during the pedagogical intervention. Some of the slogans that students selected to add meaning to their bags were inspired by authentic material from environmental campaigns from all over the world.

However, both in visual representation and linguistic representation, students used copying as a resource to complete their task of customizing the ecobag. Even though copying is often currently viewed as a form of cheating in school practices, when it comes to gathering creative semiotic modes, it can be useful to the process. Holzman (2010) highlights Vygotsky's perception of copying as "imitation" in the concept of "collective ZPD" (p. 15), since it is not exclusively or even primarily a dyadic relationship, and that people are doing something collaboratively. Holzman then reports that the creation of works should involve "freedom from knowing, creative imitation, and completion of tasks" (p. 16).

Picture 4 shows two examples in which copying occurred. In the first example, students 01, 25 and 34 drew a plant in the form of an ecological lamp to emphasize the importance of saving energy and plants. In the second example, students drew the Planet Earth in the form of an almost empty coconut, along with the question "Got more?", representing the alienation from the population towards an issue. These combinations of slogans and images were not only copied from one another, but also from previously existing sources/ materials given to students as examples to their production, during the pedagogical intervention.

Therefore, the action of copying can be congruently outlined with the concept of intertextuality (Bakhtin, 1999; Fairclough, 1997) in the sense of a text present in another text, without being totally authentic. Students from this research have recurred to tangible resources and means of representations that are present and available in their culture in order to create their ecobags. Even though they did not entirely imitate their classmates, they have imitated other texts anyway. Nevertheless, this topic lies beyond the scope of this paper. 


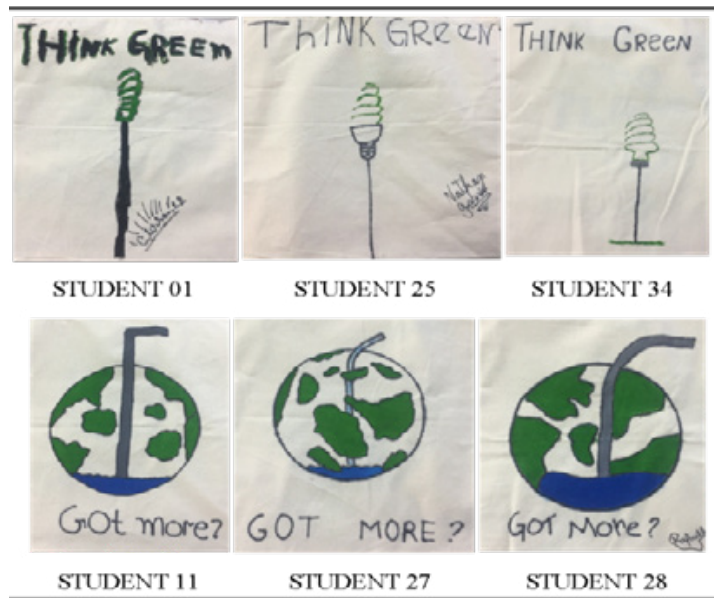

Picture 1 - Examples of copies in the customization of ecobags.

Source: The authors.
Students were labeled in the form of numbers, from 1 to 33, to facilitate data organization and sampling. This last category identifies the final project as an evidence for the students' success on building meaning out of different multimodal choices (synesthesia) or not (counterevidence). This last category also encompasses the organizational and contextual meanings of $A$ Grammar of Multimodality (2009). All multimodal choices worked together to contribute to the construction of meaning. As a result, as Kress defines it, an "orchestration of modes" (2014, p.14) in the ecobags reveals that students, at their most, succeeded in choosing multisemiotic modes of representation to achieve a specific goal, in this case, environmental awareness. The picture below exemplifies such achievements:

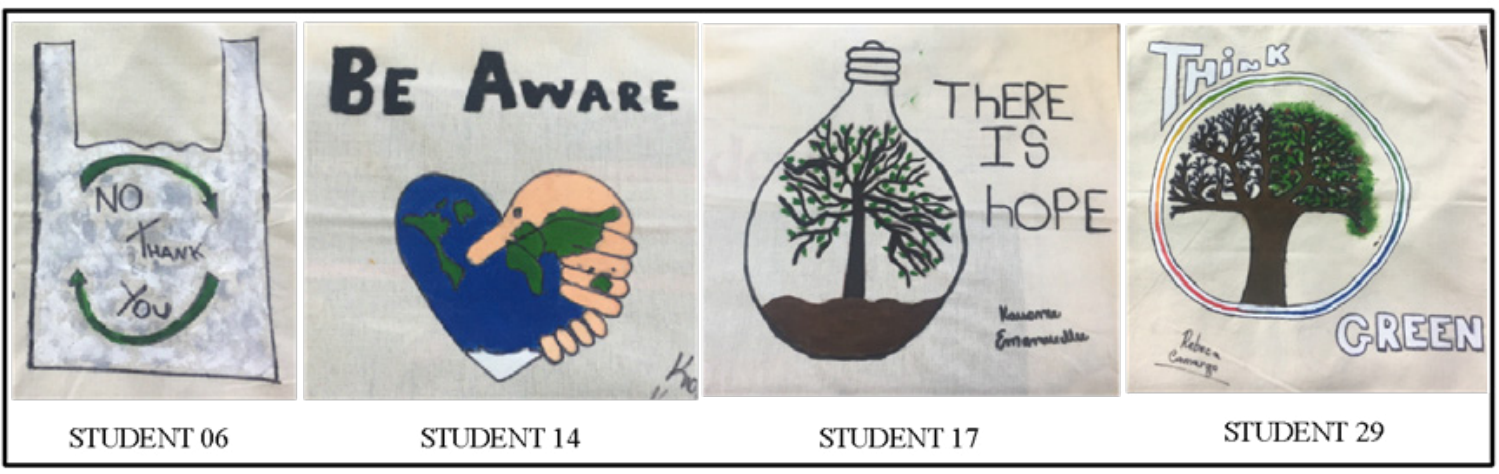

Picture 2 - Examples of students' success in multimodal choices. Source: The authors.

Student 06 chose to represent an irony. She drew and painted a plastic bag in an ecobag with the message "no thank you", surrounded by two arrows indicating sustainability concern. According to her intention file, she affirmed that she mixed the colors gray and white up to illustrate the texture of a reused plastic bag. which was reinforced by using her fingers to create such effect. Following the same line of thought, student 14 drew a heart-shaped Planet Earth that also points up to two hands holding one another, as a symbol of help, love and respect to the planet. This student mixed the colors in a way that the hands and the planet are connected, being impossible to separate one from the other, highlighted by the slogan "Be Aware".

Student 17 matched the proposal by drawing a lamp with a strong tree on the inside. The lamp is shown not only as a means of protection for the tree, but also as a reference to sustainable and renewable energy resources. The slogan "There is Hope", in capital letters and in a big font, suggests that the student intended to raise people's awareness by calling their attention to the fact that one can still do something to change the world. Furthermore, the use of dark colors may indicate that the planet's current situation is in a critical condition and people should grasp that.

In another perspective, but also portraying hope, student 29 drew a tree with half of its parts 
dry, and half of it full of leaves. The choice of colors deeply influence the strength of the message, since it creates a contrast between the sick and the healthy; the colorless and the colorful; death and life. The student also succeeded in making meaning out of her multimodal choices by placing the words from her slogan in strategic places in the ecobag. Her spatial multimodal use of the words "Think Green" may indicate that in order for you to get a better result, the "green" result, you need to think about the circumstances and act upon them. This might have happened because she evidenced the contrast between a metaphorical lifeless tree, and a lively tree, with the slogan working as a request for people to observe that and do something to change it.

Overall, synesthesia could be accomplished in most of the projects from this $9^{\text {th }}$ grade group, because in their projects, there was an "increased semiotic richness and hybridity" (Nelson, 2006, p. 71), involving both linguistic and extra linguistic evidence. Additionally, students were able to handle their modes and resources in a meaningful and effective way, creating meaning out of all their multisemiotic choices.

\section{Analysis of learning de-encapsulation}

Learning de-encapsulation (LD) was analyzed under a social and ideological perspective, aiming at dealing with these two questions from A Grammar of Multimodality (Cope \& Kalantzis, 2009): "How do the meanings connect the persons they involve?"; "Whose interests are the meanings skewed to serve?" (p. 365). However, these questions are not the only elements that were taken into account for the demonstration of the de-encapsulation. The division of labor between English teacher and Arts teacher was also validated, along with intentions and emotions felt by students when sharing their knowledge to people outside their classroom. The table below exhibits a compiled version of students' answers to their intention files, with the purpose of highlighting LD.

The first category, "Boundary crossing", indicates the range of achievement the LD had, if it was inside school boundaries, or outside. The second category regards the recipient of the ecobag. In other words, to whom students wanted to give their ecobags. It is a very relevant category, for it evidences the actual and concrete spread of learning and awareness to the community where students are inserted. Congruently, the last three categories expose the meanings behind the intentions of sharing the ecobags to the world, being divided in written mode meaning, motive and overall meaning.

TABLE 2 - Compilation of students' intention file answers.

\begin{tabular}{|c|c|c|c|c|c|}
\hline $\begin{array}{l}\text { Boundary } \\
\text { crossing }\end{array}$ & Recipient & $\begin{array}{c}\text { Meaning } \\
\text { (written mode) }\end{array}$ & Motives & $\begin{array}{l}\text { Overall } \\
\text { meaning }\end{array}$ & Students \\
\hline \multirow{4}{*}{$\begin{array}{l}\text { Within } \\
\text { school }\end{array}$} & Teacher & \multirow{4}{*}{$\begin{array}{l}\text { To raise } \\
\text { awareness }\end{array}$} & \multirow{4}{*}{ Fondness } & \multirow{4}{*}{ Gift } & $14,31,20,10,25,06,03,13,12$ \\
\hline & Pedagogue & & & & 07,04 \\
\hline & Janitor & & & & 23 \\
\hline & Principal & & & & 15 \\
\hline \multirow{3}{*}{$\begin{array}{l}\text { Out of } \\
\text { school } \\
\text { boundaries }\end{array}$} & \multirow{3}{*}{ Mother } & To save the world & To replace & To raise & \\
\hline & & To buy groceries & $\begin{array}{l}\text { the use of } \\
\text { plastic bags }\end{array}$ & $\begin{array}{l}\text { awareness } \\
\text { and as a gift }\end{array}$ & $02,11,16,18,19$ \\
\hline & & $\begin{array}{l}\text { To raise } \\
\text { awareness }\end{array}$ & Fondness & Gift & $21,27,30,32,33,34$ \\
\hline
\end{tabular}

Source: The authors. 
The categories Boundary Crossing, Recipient, Motives and Overall Meaning encompass answers from question number 5 on the Intention File: "Who do you want to give your ecobag to? Why?". Correspondingly, Meaning (written mode) is related to answers from question 4: "What message do you want to send with your ecobag?". These elements seek to identify and justify the application of the content seen inside the classroom, to "real life" situations outside the classroom.

According to the intention files' answers and through pattern detection, one aspect is present in every ecobag: the overall meaning being a gift. After hearing in the proposal of the environmental project, that students would present someone with their ecobags as a way of raising awareness in society, they started viewing the production/ customization of their project not only as an instrument to environmental care, but also as a gift to someone they admire greatly. This added a larger meaning to LD, because students could personally connect to the Social Activity, bringing a more meaningful purpose to it. In addition, this process combines with descriptions of gestural representation, also present in A Grammar of Multimodality (Cope \& Kalantzis, 2009, p. 4) for such representation "may take the form of feelings and emotions" (p. 4), with a "visible sentiment" (p. 8).

In consonance, LD occurred in several forms in this social activity. One of them was the interdisciplinary practice. Besides bringing benefits to both subjects, this practice allowed students to mix and experience knowledge involving different forms and concepts, extrapolating English classes' walls. In this matter, students dealt with modes in linguistic and artistic ways, with the help of two teachers specialized in two different areas, but making meaning together, and working collectively with the students.

LD also happened with the distribution of the ecobags to individuals outside the English classroom. Moved by affection and eagerness to make a difference, students bestowed their dear ones with materials produced by them, with a specific knowledge, carried with a meaning. This allowed the project to reach a more sensitive meaning, making more sense to students' reality and daily life, in which they were able to use language as a means of social practice and agency into the world.

\begin{abstract}
De-encapsulation builds on the notion of an ecology of knowledges (Santos, 2006) as central to environments where creativity, innovation and transformation flourish. De-encapsulated practices challenge pre-established truths and value multiculturalism, through an open and continuous process of construction and deconstruction, which results from the interactions between people of different cultural backgrounds. It is not limited to the acceptance of various cultures but is characterized by a movement of appreciation and approximation between them, a disposition which should also be addressed in schools (Freire, 2003). (Liberali, 2017, p. 96)
\end{abstract}

In summary, this social activity was analyzed in a double perspective, taking into account the research questions which aimed at exploring the affordances of multimodality and learning de-encapsulation in this environmental project. The first question regards the ultimate meaningmaking process of students while dealing with multi-semiotic ways of representation. Through an orchestration of modes, students were able to choose visual representations, such as colors, shapes, and texture, alongside with a linguistic representation (the slogan), and spatial representation, by placing elements in strategic positions on the ecobag to pass a specific message. Overall, most students were successful in accomplishing a multimodal meaning in this task.

Moreover, the second research question addresses the classroom boundary-crossing that the projects attained. By carrying the purpose of approximating school's subjects to students' daily lives, learning de-encapsulation played an essential role in this task. Students thrived in making use of the environmental knowledge they had acquired in English classes, since it reached not only spaces inside the school, but also outside its walls. This happened within English Language and Arts interdisciplinary practice, as well as with the distribution of the ecobags.

\section{Conclusion}

This paper aimed at describing and analyzing the outcomes of a pedagogical intervention 
emerged from a real-life necessity from the school community and students from the $9^{\text {th }}$ grade of a state school. This necessity is here characterized as a Social Activity (Liberali, 2009), aligned with the principles of the Social Historical Activity Theory (Engestrom, 1999). In the proposal, students were in contact with environmental education, slogans, and campaigns from all over the world, encouraging the practice of critical thinking and planetary awareness inside the classroom.

Furthermore, the results from this research indicate that students managed to deal with several multi-semiotic modes of representation and, as a result, assemble a multimodal meaning. In the process, they customized ecobags, with the help of philanthropical grants and the enriching interdisciplinary practice with the Arts teacher. Based on the analysis of the findings, students benefited from such practices and were able to create meaning and project them outside English classes' limits.

On the other hand, having concluded this research, internship period, and, therefore, data collection period, I concluded that maybe recording videos of classes from the intervention might have been more profitable since it shows the process with more details and accuracy. Perhaps the process of choosing how to deal with resources and combining them in their ecobags would have been better analyzed and portrayed through image and sound recordings.

All in all, this research may work as an invitation to other researchers, teachers, and teachers in-formation to reflect upon the implications of having interdisciplinary practices taken out of school curriculums and put into practice. Besides that, environmental education needs to gain more space in classroom practices; there is no doubt of the impacts caused by society in our planet. In addition, readers might consider bringing English classes closer to students' daily routine, in a way that is meaningful for them, deriving from an outgoing necessity. This way, learning is used not only inside English classes, but also in the active community of the school and city where they live.

\section{References}

Belloni, M. L. (2001). Educação a distância. Autores Associados.

Bezerra, F. (2011). Multimodality in the EFL classroom Belt journal, 2(2), 167-177. https://revistaseletronicas.pucrs.br/ojs/index.php/belt/article/downlo$\mathrm{ad} / 9671 / 7551 /$.

Brasil. (1988). Constituição Federal de 1988. Promulgada em 5 de outubro de 1988.

Brasil. (1999). Politicas Nacionais de Educação Ambiental - PNEA. Diário Oficial da República Federativa do Brasil.

Brasil. (2005). Programa Nacional de Educação Ambiental - PRONEA (3. ed). Ministério do Meio Ambiente.

Brasil. (2013). Anuário Brasileiro da Educação Básica. Todos pela educação. Ed. Moderna.

Brasil. (2017). Base Nacional Comum Curricular: Educação infantil e ensino fundamental. MEC/Secretaria de Educação Básica.

Brener, F. M. (2018). Práticas de letramentos literários multimodais na formação do professor. [Doctoral dissertation, Universidade Estadual de Maringál. UEM Campus Repository. http://www.ple.uem.br/defesas/ def_fernanda_machado_brener_do.html

Castanha, M. (2008). A linguagem visual no livro sem texto. In Oliveira, I. de (Org.), O que é qualidade em ilustração no livro infantil e juvenil: com a palavra o ilustrador (pp.141-161). DCL.

Cope, B., \& Kalantzis, M. (2009). A grammar of multimodality. The international journal of learning, 16(2), 361-426. http://www.learning-journal.com

Cope, B., \& Kalantziz, M. (Eds.). (2000). Multiliteracies. Literary learning and the design of social futures. Routledge.

Cristovão, V. L., Radi, A. J., \& Santana, P. A. (2016). O uso da língua inglesa como instrumento para a educação ambiental na formação profissional. Revista Interfaces, 7(3), 97-115. https://revistas.unicentro.br/index.php/ revista_interfaces/article/view/4617

Cruz, N. P. (2009). Narrativas visuais: múltiplos olhares, leituras plurais [Dissertação de mestrado, Universidade De Santa Cruz Do Sul]. http://repositorio.unisc.br/jspui/ bitstream/11624/464/1/nelmacruz.pdf

Crystal, D. (2003). English as a global language. Cambridge University Press.

Cunha, A. C. (2005). Livro de imagem: aprender a ver para aprender a ler [Dissertação de mestrado, Universidade Federal de Pernambuco]. http://repositorio.ufpe.br/ bitstream/handle/123456789/7978/arquivo8404_1. pdf? sequence $=1 \&$ isallowed $=y$

Dias, G. F. (1991). Educação ambiental: principios e práticas (8. ed.). Gaia.

Elliott, J. (1991). Action Research for Educational Change Open University Press.

Engestrom, Y. (2002). Aprendizagem por expansão na prática: em busca de uma reconceituação a partir da teoria da atividade. Cadernos De Educação, 19. 31-64. 
Engestrom, Y., Miettinen, R., \& Punamaki, R. L. (1999). Perspectives on activity theory. Cambridge University Press.

Ervin-Tripp, S. (1973 [1954]). Identification and bilingualism. In S. Ervin-Tripp (Ed.), Language Acquisition and Communicative Choice (pp. 433-453). Stanford University Press

Ferreira, C. C. (2019). Encantamento e reflexões à luz do imagético: a narrativa visual na contação de histórias In Miranda, C. V. M., \& Ferreira, C. C. (Eds.), Reflexões, diálogos e perspectivas sobre literatura e ensino (pp. 129-164). Pontes.

Fracalanza, H. (2004). As pesquisas sobre educação ambiental no brasil e as escolas: alguns comentários preliminares. In Tablieber, J. E. \& Guerra, A. F. S. (Eds.), Pesquisa em educação ambiental (pp. 55-77). UFPEL.

Heberle, V. (2010). Multimodal literacy for teenage EFL students. Caderno de letras (UFRJ), (27), 101-116. https:// www.researchgate.net/publication/293183989_Multimodal_literacy_for_teenage_EFL_students

Heinich, R.; Molenda, M., Russell, J. D., \& Smaldino, S. E. (1999). Instructional media and technologies for learning (6. ed.). Prentice-Hall.

Holzman, L. (2010). Vygotsky \& Creativity: a cultural-historical approach to play, meaning-making and the arts. Peter Lang Publishers.

Kress, G., \& Van Leeuwen, T. (2010). Reading images: the grammar of visual design (2. ed.). Routledge.

Kumaravadivelu, B. (2005). Understanding language teaching: from method to postmethod. Routledge.

Larré, J. (2018). Atividade social acadêmica no ensino de lingua inglesa on-line: o que os aprendizes nos dizem sobre isso? Revista Brasileira de Linguística Aplicada, 18(3), 531-560.

Lave, J., \& Wenger, E. (1991). Situated Learning: Legitimate Peripheral Participation. Cambridge University Press.

Leffa, V. J. (1999). O ensino de línguas estrangeiras no contexto nacional. Contexturas, (4), 13-24.

Leffa, V. J., \& Irala, V. B. (2014). O ensino de outra(s) língua(s) na contemporaneidade: questões conceituais e metodológicas. In Vilson J. Leffa; Valesca B. Irala (Eds.), Uma espiadinha na sala de aula: ensinando linguas adicionais no Brasil (pp. 21-48). Educat.

Leontiev, A. N. (1983). Actividad, conciencia, personalidad. Editorial Pueblo Y Educación.

Libâneo, J. C. (2004). A aprendizagem escolar e a formação de professores na perspectiva da psicologia histórico-cultural e da teoria da atividade. Educar Em Revista, (24), 113-147.

Liberali, C. F., Magalhães, M. C. C, Meaney, M. C, Santiago, C., Canuto, M. \& Santos, J. A. A. Dos. (2015). Projeto digit-m-ed brasil: uma proposta de desencapsulação da aprendizagem escolar por meio dos multiletramentos. Revista Prolingua, 10(3), 2-17.

Liberali, F. C. (2009). Atividade social nas aulas de língua estrangeira. Moderna.
Lück, H. (2003). Pedagogia interdisciplinar: fundamentos teórico-metodológicos (11. ed.). Vozes.

Marx, K. (1989). Manuscritos econômicos-filosóficos In Fernandes, F. (Ed.), Marx E Engels: história (pp. 147181). Ática.

Miranda, C. \& Ferreira, C C. (Eds.). (2019). Reflexões, diálogos e perspectivas sobre literatura e ensino. Pontes Editores.

Miranda, F, Miranda, J, \& Ravaglia, R. (2010). Abordagem interdisciplinar em educação ambiental. Revista Práxis, ano II, (4), 11-16.

Miranda-Zinni, A. V., \& Weiler, S. (2011). Produção oral e performance: uma forma de aprender novas formas de pensar e agir no mundo. In Cano, M. R. De O. (coord.); Liberali, F. C. (Ed.), A reflexão e a prática no ensino: inglês (v. 2, pp. 97-111). Blucher.

New London Group. (2006). A pedagogy of multiliteracies: designing social futures. Routledge.

Oliveira, I. De (Ed.). (2008). O que é qualidade em ilustração no livro infantil e juvenil: com a palavra o ilustrador. DCL.

Oliveira, M. B. F. De, \& Szundy, P. T. C. (2014). Práticas de multiletramentos na escola: por uma educação responsiva à contemporaneidade. Revista Bakhtiniana, 9(2), 113-146.

Piaget, J. (1980). The psychogenesis of knowledge and its epistemological significance. In M. Piatelli-Palmarini (Ed.), Language And Learning (pp. 23-34). Harvard University Press.

Rezende, V. A. (2013). A dimensão ambiental na educação de jovens e adultos: possibilidades e desafios. Revista Tempos E Espaços Em Educação, 67-76. https:// doi.org/10.20952/revtee.voi0.2542

Richter, C. L. (2015). O ensino da lingua inglesa à luz de atividades sociais na esfera acadêmica local: quando a linguagem, a lingua e a universidade encontram-se para oferecer escolhas ao aluno da graduação [Dissertação de mestrado, Universidade Federal De Pernambuco]

Rodrigues, M. L. C. (2012). A narrativa visual na literatura infantil brasileira: histórico e leituras analiticas. Univille.

Royce, T. (2007). Multimodal communicative competence in second language contexts. In Royce, T., \& Bowcher, W. (Ed.), New directions in the analysis of multimodal discourse (pp. 361-403). Lawrence Erlbaum.

Sannino, A., Daniels, H., \& Gutiérrez, K. (2009). Learning and expanding with activity theory. Cambridge University Press.

Silva, S. A. S. (2017). Atividade social e multiletramentos: aprendizagem não encapsulada de conceitos na relação escola e sociedade [Doctoral dissertation, Pontificia Universidade Católica de São Paulo]. PUCSP Campus Repository. https://sapientia.pucsp.br/handle/ handle/19937.

Skinner, B. F. (1978). Reflections on behaviorism and society. Prentice-Hall.

Sousa, G. L. De., Medeiros, B. A., Mendonça, F. J. S. L., \& Oliveira, I. P. (2011). A importância da educação ambiental na escola nas séries iniciais. Revista Eletrônica Faculdade Montes Belos, 4(1), 1-17. 
Tilio, R. (2014). Lingua estrangeira moderna na escola pública: possibilidades e desafios. Educação Real, 39(3), 925-944

Tripp, D. (2005). Action research: a methodological introduction. Educação e Pesquisa, 31(3), 443-466.

UN (1972). Stockholm declaration on the human environment. In Report of The United Nations Conference On The Human Environment.

UNESCO-UNEP. (1976). The Belgrade Charter: a global framework for environmental education. UNESCO.

Vygotsky, L. S. (1984). A formação social da mente. Martins Fontes.

Vygotsky, L. S. (1978). Mind in society. Harvard University Press.

Wileman, R. E. (1993). Visual communicating. Educational Technology Publications.

Zavala, V. (2018). Language as social practice: deconstructing boundaries in intercultural bilingual education. Trabalhos Em Linguistica Aplicada, 57(3), 1313-1338. Https://doi.org/10.1590/010318138653255423542

\section{Carolina Favaretto Santos}

Graduada em Letras-Inglês pela Universidade Estadual de Londrina (UEL), em Londrina, PR, Brasil; mestranda em Letras Estrangeiras Modernas na Universidade Estadual de Londrina (UEL), em Londrina, PR, Brasil; professora de inglês no Centro Binacional Instituto Cultural Brasil - Estados Unidos, em Londrina, PR, Brasil; servidora da Prefeitura Municipal de Ibiporã como professora de Língua Inglesa, em Ibiporã, PR, Brasil.

\section{Denise Ismenia Bossa Grassano Ortenzi}

Doutora em Estudos da Linguagem pela Universidade Estadual de Londrina (UEL), em Londrina, PR, Brasil; mestre em Linguistica Aplicada pela Universidade Estadual de Campinas (UNICAMP), em Campinas, SP, Brasil; professora adjunta da Universidade Estadual de Londrina (UEL), junto ao Programa de Pós-Graduação em Letras Estrangeiras Modernas - Mestrado Profissional, em Londrina, PR, Brasil.

\section{Endereço para correspondência}

Denise Ismenia Bossa Grassano Ortenzi

Universidade Estadual de Londrina

Centro de Letras e Ciências Humanas

Departamento de Letras Estrangeiras Modernas

Av. Celso Garcia Cid, s/n

86051-970

Londrina, PR, Brasil
Os textos deste artigo foram conferidos pela Poá Comunicação e submetidos para validação do(a) autor(a) antes da publicação. 